\title{
A leggyakoribb nemi betegségekre vonatkozó ismeretek középiskolai pedagógusok számára I. rész
}

Knowledge of the most common genital diseases

for high school teachers Part I

\author{
Szerzők: Burián Katalin $\bowtie$, Spengler Gabriella \\ Szegedi Tudományegyetem, Általános Orvostudományi Kar, Orvosi Mikrobiológiai és \\ Immunbiológiai Intézet, Szeged
}

Beküldve: 2017.09. 05.

doi: 10.24365/ef.v58i3.175

\begin{abstract}
A nemi betegségekről, a terjedési módokról, a betegséget kiváltó kórokozókról a szexuális élet megkezdése előtt a fiataloknak megfelelő tudásanyaggal kellene rendelkezniük. A téma viszont rendkívül kényes, nehéz beszélni róla, még a harmonikus családban élő fiatalok számára is. Az iskolai biológia- és egészségtanórák tempója is meglehetősen feszes, így ez a témakör kevésbé ismert fiatalok között. A szerzők a rendszertani kategóriákat követve (vírusok, baktériumok, gombák, véglények) bemutatják azokat a Magyarországon gyakrabban előforduló mikroorganizmusokat, amelyek nemi betegséget okozhatnak. Ismertetésre kerülnek a különböző nemi betegségeket kísérő tünetek és panaszok, amelyek felhívják a fertőzött személy figyelmét a betegségre. Ahhoz, hogy ezek a betegségek elkerülhetők legyenek, a fiataloknak tudatában kell lenniük, hogy ezek a kórokozók nemcsak az intim szexuális együttlét során, hanem a szexuális szokásoktól függően nyálkahártyán keresztül, akár orálisan is terjedhetnek. Fontos arról is tudni, hogy ezek a mikroorganizmusok mennyire ellenállóak a környezetükben, számíthatnak-e fertőzésre uszodában vagy mellékhelységben. A téma megismertetésében a szakemberek segítsége a biológiatanárok és a tanulók részére tartott iskolai előadások keretében sokat javíthatna.
\end{abstract}

Kulcsszavak: nemi betegségek, vírus, baktérium, gomba

Teenagers should have appropriate knowledge related to the genital diseases, pathways of their transmission, and the symptoms of the diseases before the starting of sexual activity. However, the topic is extremely delicate; it is difficult to talk about it even for young people living in a harmonious family. The pace of school biology and health lessons is quite tense. Thus, this topic is less well-known among young people, authors present the more commonly occurring microorganisms in Hungary that can cause genital disorders, according to the taxonomic categories (viruses, bacteria, fungi, endemics). The symptoms that accompany the various sexually transmitted diseases are described, which draw the infected person's attention to the fact that something is unorganized in the body. In order to avoid sexually transmitted diseases, young people should be aware that these pathogens can spread not only during sexual intercourse but also through the mucous membrane or the oral cavity, depending on sexual habits. It is also important to know how resistant these microorganisms are in the environment, or if they can contract an infection in a swimming pool or in a restroom. Lectures for biology teachers and students held by professionals could highly improve the general understanding of this topic.

Keywords: sexual diseases, virus, bacterium, fungus 


\section{BEVEZETÉS}

A testi és lelki egészségre nevelés az iskolai nevelőoktató munka során kiemelt fontosságú [110/2012. (VI. 4.) Korm. rendelet a Nemzeti alaptanterv kiadásáról, bevezetéséről és alkalmazásáról], azaz értékálló és a kor igényeinek megfelelő tudást kell átadni a tanítványoknak. Az egészségnevelés terén a fertőző betegségek megelőzésével kapcsolatban számos új kihívással szembesül a pedagógus, és a szakszerű és hasznos ismeretek átadását a rendelkezésre álló idő, a pedagógusok tájékozottsága, valamint a diákok szociális háttere is befolyásolja.

A szexuálisan terjedő betegségekről nehéz beszélni iskolai keretek között, de megkerülhetetlen. Fontos, hogy a tanulók megbízható, pontos tudással rendelkezzenek ezen a téren is, ne csak egymástól vagy sokszor a megbízhatatlan internetes forrásból szerezzék ismereteiket. Az egészségfejlesztés keretében a fertőző betegségek, köztük a szexuálisan átvihető kórokozóknak és a betegség tüneteinek ismerete elengedhetetlen. Szexuális úton terjedhetnek olyan mikroorganizmusok, amelyek kizárólag vagy fóleg a nemi szerveken okoznak elváltozást. Ezek mellett vannak olyan kórokozók, amelyek bár szexuális úton is terjedhetnek, nem ott okoznak tüneteket, hanem más szervet érintenek, vagy sokszor szisztémás megbetegedést okoznak, idetartozik pl. a hepatitis B-vírus által okozott májgyulladás vagy a HIVfertőzés miatt kialakuló AIDS (szerzett immunhiányos szindróma). Jelen esetben azok a mikroorganizmusok kerülnek tárgyalásra, amelyek a nemi szerveket érintő megbetegedéseket alakítanak ki. Rendszertanilag a skála széles, a nemi betegségek okozója lehet vírus, baktérium, gomba és nem utolsó sorban véglény (protozoon) is.

\section{HERPES GENITALIS (GENITÁLIS HERPESZ)}

A genitális herpeszt a herpes simplex vírus 1 (HSV1) és 2 (HSV-2) okozza. A humán herpeszvírusok DNS-tartalmú, külső borítékkal rendelkező vírusok, világszerte igen elterjedtek. A herpeszvírusok legfontosabb jellemzője, hogy az első fertőzést követően - bár az általuk okozott elváltozás elmúlik - nem pusztulnak el, hanem lappangó alakban túlélnek a gazdaszervezetben. A herpes simplex vírus 1 és 2 az elsődleges behatolás helye körüli idegdúcokban találhatók lappangó, látens formában. Általában az elsődleges fertőzés is tünetek nélkül zajlik, tehát a fertőzött egyén nem is tud arról, hogy később esetleg időnként üríti a vírust. Fontos tudni a herpeszvírusokról, hogy a tudomány mai állása szerint nem lehet őket kiirtani a szervezetből, tehát életünk végéig bennünk maradnak. Bizonyos tényezők hatására a lappangó vírus újra aktiválódhat, az idegvégződéseken visszavándorolhat az elsődleges laesio helyére, és ott hasonló elváltozást okozhat, vagy éppen tünetmentesen ürülhet a különböző testváladékokkal. Nagyon sok tényező aktiválhatja a lappangó vírust, így füszeres ételek, napfény, stressz, mechanikai irritáció, menstruáció, az immunrendszer meggyengülése, kimerültség stb. A herpes simplex vírus 2 felelős a genitális herpeszek 90\%-áért, a szexuális szokásoktól függően a herpes simplex vírus 1 (amely az úgynevezett ajakherpeszt okozza) pedig az esetek 10\%-ában fordul elő. Az ajakherpeszt illetően fontos tudni, hogy jelenlétekor a nyál is tartalmaz vírusokat, így súlyos szaruhártya-fertőzést okozhat magának, aki a kontaktlencséjét nyállal helyezi fel. Bármely vírus átvihető tehát a szexuális együttlét során, akár oly módon, hogy egyik partnernek sincsenek tünetei. Amennyiben tünetek jelentkeznek, a legfontosabbak közé tartozik az égő, viszkető érzés az érintett nyálkahártyán, bőrön, nők esetében a kisajkakon, a végbél környékén, a hüvelyben, míg férfiak esetén a húgycső, a pénisz, a herezacskó és a végbéltájék lehet érintett. Kezdetben egy piros folt, majd annak helyén egy kis, tiszta bennékü hólyag jelenik meg, amely később pörkösödve gyógyul. A hólyag nagy mennyiségű vírust tartalmaz. Sajnos a fertőzött egyének egy részében a vírus egy évben többször is reaktiválódhat, ami ha tünetekkel jelentkezik, alaposan megkeseríti a beteg mindennapi életét. A herpeszvírusok igen érzékenyek, ez pedig azt jelenti, hogy a külvilágba kikerülve nem képesek sokáig fertőzésre, tehát közös használatú WC-n nem kaphatunk fertőzést. A terjedésével kapcsolatban érdekes az a tény, hogy a vírus nagyobb valószínűséggel terjed férfiról nőre, mint fordítva. A herpeszvírus okozta elváltozások kezelésében antivirális szereket használnak. Ezek a szerek gátolják a vírusok szaporodását, de nem tudják kipusztítani a vírust a szervezetből. ${ }^{1,2}$ 


\section{CONDYLOMA ACUMINATUM \\ (NEMI SZERVI SZEMÖLCS)}

A nemi szerveken előforduló szemölcsöket a humán papillomavírusok (HPV) különböző típusai okozhatják, leggyakrabban a HPV6 és 11. A HPV-k DNS-tartalmú, kisméretű, boríték nélküli vírusok. Ennek köszönhetően a külvilágban rendkívül ellenállóak. Élettelen felszíneken fertőzőképesek maradnak hosszú ideig. A HPV-k a bőrön vagy a nyálkahártyán levő kis, sokszor láthatatlan sérüléseken keresztül fertőzik meg a bőr mélyebben fekvő, úgynevezett bazális sejtjeit. A fejlődő, differenciálódó bazális sejtek egyre jobban közelednek a felszín felé, és a bennük levő vírusok velük együtt érnek. A vírusok bizonyos fehérjéi fokozzák a sejtek szaporodását, ez a szaporodás eredményezi a látható szemölcsöt. Fertőzőképes vírusok csak a bőr, illetve nyálkahártya legkülső rétegéből ürülnek a leváló sejtekkel. A genitális szemölcs előfordulhat egyesével, de több kis szemölcs karfiolszerű kitüremkedést is formálhat. A genitális szemölcsök jóindulatúak. Léteznek viszont olyan magas kockázatú HPV-k, például a 16-os és a 18-as típusok, amelyek beépülnek a gazdasejt kromoszómájába, és rosszindulatú daganatot, például méhnyakrákot okozhatnak. Egészséges immunrendszer esetén a szemölcsök maguktól is visszafejlődhetnek, még azok az elváltozások is, amelyeket magas kockázatú HPV-típusok okoznak. Tehát ha valakiben onkogén papillomavírust mutatnak ki, például a HPV16-ot, az nem jelenti azt, hogy rákos lesz, az esetek $80 \%$-ában ugyanis a szervezet képes a vírus hatástalanítására.

A HPV okozta szemölcsök felszámolására a helyi kezelés során a szemölcsöt pusztító savat, toxint lehet alkalmazni, vagy a szemölcsök sebészeti és egyéb úton is eltávolíthatók (lézerrel, fagyasztással, illetve hőkezeléssel). A méhnyakrák, valamint a nemi szerveken és környékükön előforduló daganatok megelőzésére ma már háromféle vakcina áll rendelkezésre: az egyik típus a leggyakrabban méhnyakrákot okozó HPV16-os és 18-as genotípusokat tartalmazza, míg az úgynevezett 4-komponensű vakcina ezen típusok mellett a leggyakrabban genitális szemölcsöt okozó (HPV6, 11) típusokat is magába foglalja. A legújabb fejlesztésű HPV-vakcina 9-komponensű, a fent említett négy típuson kívül további ötféle (HPV31es, 33-as, 45-ös, 52-es és 58-as) típus vírusszerű részecskéit tartalmazza. A vakcinában nincs jelen a vírus-DNS, így rákot sem tud okozni, a közhiedelemmel ellentétben. A védőoltásban csak a vírusburok fehérjéje van benne (vírusszerú részecske), amely ellen, ha a szervezetbe kerül, ellenanyag-termelés indul meg. A későbbi esetleges természetes fertőzést követően ezek az ellenanyagok képesek a vírusokat semlegesíteni. A hatékony ellenanyagválasz eléréséhez a védőoltást még a szexuális élet megkezdése előtt két adagban adják. A vakcina nemcsak a kérdéses típusok ellen lehet hatásos, hanem más HPV típusok ellen is. A HPV-vakcinák a klinikai vizsgálatokban és oltási programokban szerzett tapasztalatok alapján hatékonyak, de fontos megemlíteni, hogy az oltásban részesült egyénekben is kialakulhat rákmegelőző vagy rákos elváltozás, amit másfajta HPV-típus okozhat, amely ellen a vakcina nem véd. Ezért az aktív nemi életet élő nők körében a nőgyógyászati vizsgálat során készített kenet szövettani vizsgálata továbbra is elengedhetetlen. ${ }^{3,4}$

HPV-ellenes védőoltási iskolai program a világ számos országában folyik, igen jó eredménnyel. Magyarországon a 2017/2018-as tanévben harmadik éve ajánlják fel minden 12 éves leánynak a HPV-ellenes védőoltást, akik a szüleik döntése alapján ezt örvendetesen magas, $80 \%$ körüli arányban meg is kapják. Jelenleg ez az egyetlen szülői döntéstől függő védőoltás az iskolai programban, így igen fontos volna az is, hogy az oltandók megfelelően tájékozottak legyenek ennek jelentőségéről.

\section{MOLLUSCUM CONTAGIOSUM („USZODASZEMÖLCS”)}

A kórelváltozás magyar elnevezése kicsit megtévesztő, mert nem a klóros vízben él a kórokozó, hanem az uszodai felületeken, tárgyakon. A molluscum contagiosum okozója a Poxvírus családba tartozó (ebbe a családba tartozott a rettegett, de mára már a Földön felszámolt fekete himlő vírusa is), humán patogén, fénymikroszkóppal is látható, DNS-tartalmú vírus, a molluscum contagiosum vírus. Ez a vírusfertőzés gyakorinak tekinthető a gyermekek körében. Könnyen megtelepszik a vékonyabb bőrfelületeken, fiatalokban, fiatal felnőttek esetében a genitáliák 
környékén. Rendkívül fertőző, a szexuális élet során könnyen átvihető direkt kontaktussal, fertőzött bőrbőr érintkezésével, valamint törölközővel, kontaminált játékszerrel. A betegek az érintett terület kaparásával további szemölcsöket okozhatnak magukon. A szemölcs a bőrből félgömbszerúen kiemelkedő 2-5 mm nagyságú, a közepén köldökszerűen behúzódó bőr színű vagy vöröses színű elváltozás. Kezelés hiányában is meggyógyul, ha ép az immunrendszer, viszont mivel rendkívül fertőző, a többi ember érdekében és az önfertőzés elkerülése miatt el kell távolítani. Ez történhet otthoni ecseteléssel vagy sebészeti úton (kaparás, lézer, fagyasztás) egészségügyi intézetben. ${ }^{5}$

\section{GONORRHOEA (TRIPPER VAGY KANKÓ)}

A gonorrhoeát a Neisseria gonorrhoeae baktérium terjeszti. A kórokozó a mikroszkóp alatt sokszor párosával látható a klinikai mintákban. Általában csak a méhnyak hengerhámját fertőzi meg, de a menstruáció megindulása előtt a hüvely el nem szarusodó hámja bizonyos hormonoknak még nem kitett, így megfertőződhet. A baktérium rendkívül érzékeny, ez abban is megnyilvánul, hogy a külvilágba kikerülve azonnal elpusztul. Tehát ezt a betegséget nem lehet elkapni például a közhasználatú WC ülőkéjén. Terjedéséhez intim együttlét szükséges (kivétel, ha a fertőzött anyáról a szülés alkalmával jut át az újszülöttre, ekkor viszont a fertőzés a szemre lokalizálódik). A baktériumok gyulladást keltenek a fertőzés helyén, amelynek eredménye lesz a gennyes folyás. Nőknél előfordul, hogy a fertőzés szinte minimális tünetekkel jár, ami azt a veszélyt rejti magában, hogy a nő tudta nélkül továbbfertőzi a partnereit. A férfiaknál a fertőzés szinte mindig tüneteket okoz, különösen a vizelés befejeztével erősödik a szúró fájdalom, és ezt kísérheti a gennyes váladék ürülése a húgycsőből. A szervezetünk megpróbálja a kórokozót eliminálni, de ez nem sikerül. Mindkét nemben előfordulnak krónikus fertőzések, ami azt jelenti, hogy a kórokozó huzamosabb ideig a szervezetben marad, gyulladást kelt, miközben felfelé vándorol. Nőknél az esetek egy részében megtelepszik a petevezetékben és ott alakít ki gyulladást. Sajnálatos módon a huzamos ideig fennálló gyulladás hegesedéshez vezet, ami viszont elzárja a petesejt útját. Kialakulhat továbbá krónikus kismedencei gyulladás, amely görcsös fájdalommal jár, és szomorú következménye a méhen kívüli terhesség vagy rosszabb esetben a terméketlenség. A baktérium a fertőzött nők 1\%ában bekerülhet a véráramba, és ízületi gyulladást, gennyes bőrfertőzést, máj környéki gyulladást, illetve agyhártyagyulladást is okozhat. Az akut fertőzést kezelés hiányában férfiak esetében is felszálló, krónikus gyulladás követi, leggyakrabban a mellékherét, a prosztatát és az ondóvezetéket érintve. ${ }^{6,7}$

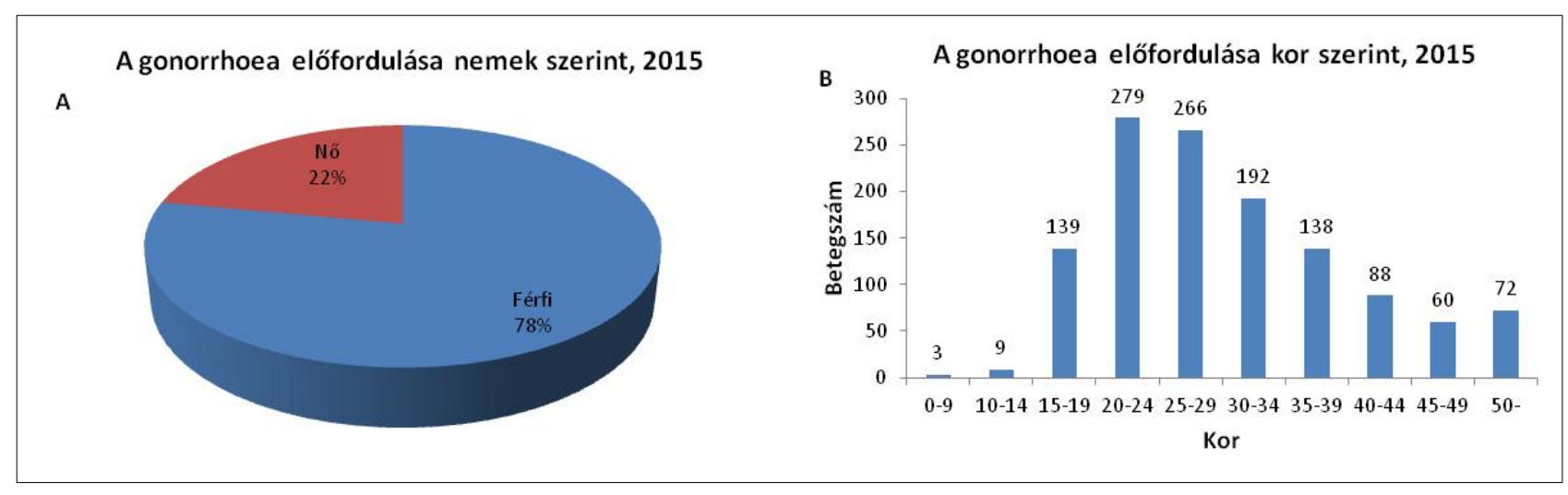

Forrás: Epinfo, 2015 (saját szerkesztésű ábrák) 
A kórokozó megtelepedése, az elsődleges fertőzés helye a szexuális szokásoktól függ. Talán sokak számára nem ismert tény, hogy ennek megfelelően egyre gyakrabban okoz az orális szexuális együttlét következtében torokgyulladást, illetve az anális szexuális kapcsolat végbélgyulladást eredményezhet. Az 1. ábrán látható adatok alapján elmondható, hogy a gonorrhoea már Magyarországon is előfordul a középiskolás korúak között is. ${ }^{8}$

\section{AKUT UROGENITALIS CHLAMYDIASIS}

Napjainkban a nyugati országokban nagy figyelmet kapott ez a kórokozó, ugyanis sajnálatos módon nagyfokú ellenálló képességre (rezisztenciára) tett szert az antibiotikumok ellen. Ez olyan fokot ért el, hogy a kutatók egy része aggódik amiatt, hogy hamarosan nem fogjuk tudni kezelni a betegeket. A kórkép okozói igen kisméretú baktériumok, a Chlamydia trachomatis D-K szerotípusai, amelyek kétféle alakban léteznek. Önálló szaporodásra képtelenek, mert bizonyos fehérjéket, enzimeket kódoló gének hiányoznak belőlük. Így csak élő sejtben tudnak szaporodni. A C. trachomatis az esetek 70\%-ában nem idéz elő tüneteket nőkben, viszont sokszor visszafordíthatatlan károkat okoz. A méhnyak hámját fertőzi meg, méhnyakgyulladást (cervicitist) okozva. Legfontosabb tünete nők esetében a folyás, esetleg csípő, szúró érzés a vizeletürítés során, de a nők nagy többségénél ez nem jelentkezik, így a baktériumot könnyen továbbadhatják a szexuális együttlét során, ami hozzájárul a kórokozó gyors terjedéséhez Amennyiben az akut gyulladást nem kezelik megfelelően, a baktérium a felsőbb nemi szervekre, a petevezetékre is ráterjedhet, annak gyulladását okozva. A krónikus kismedencei chlamydiafertőzés szövődménye lehet - hasonlóan a krónikus gonorrhoeás fertőzéshez - a petevezető elzáródása és ennek következtében a méhen kívüli terhesség, valamint a terméketlenség is. A férfiakban hasonlóan nőkhöz - jelentkezhet rendellenes folyás, égető érzés, amely a vizeletürítéshez kötött, valamint a herék fájdalmas duzzanata alakulhat ki. ${ }^{9}$ $\mathrm{Az}$ urogenitalis chlamydiafertőzés világszerte rendkívül gyakori, 2015-ben 61 millió esetet regisztráltak, az USA-ban 1,4 milliót. 9,10 Magyarországon a chlamydiafertőzéseket, amennyiben diagnózisra kerülnek, kötelezően be kell jelenteni. 2015-ben az Országos Epidemiológiai Központ adatai alapján 965 esetet regisztráltak, ebből a 1519 éves korosztályban 86 megbetegedés történt. ${ }^{8}$ Természetesen ezek a számok csak a jéghegy csúcsát jelentik. A chlamydiafertőzéseket megfelelő antibiotikumokkal kezelik. Sajnos nem mindig sikeres a terápia, aminek hátterében sokszor az áll, hogy a kórokozó speciális alakot vesz fel, amelyre az antibiotikum kevésbé hat, így életképes marad és a későbbiekben ismételt gyulladást okozhat.

\section{SZIFILISZ (VÉRBAJ)}

A szifilisz kórokozója spirális alakú baktérium, a Treponema pallidum pallidum alfaja. A szexuális átvitelen kívül a méhlepényen keresztül a magzatot is megfertőzheti és terjedhet vérrel vagy vérkészítménnyel is. A szifilisz első tünete mindkét nemben az elsődleges tályog (primer sánker), amely kemény alapú, fájdalmatlan fekély és általában a nemi szerveken fordul elö, de a szexuális szokásoktól függően jelentkezhet a szájüregben, például a nyelven is. A fekély rendkívül fertőző, nagy számban található benne baktérium, amely könnyen átvihető a partneren levő apró sérüléseken keresztül. A fekély két hónapon belül nyomtalanul elmúlik, ami a betegben hamis gyógyultságtudatot kelt. A baktérium viszont nem pusztul el, hanem bekerül a keringésbe és néhány hét múlva újabb tüneteket okoz, ezek a testszerte (még a talpon és a tenyéren is) megjelenő piros kiütések, valamint föleg a nemi szervek környékén megjelenő nagy, lapos szemölcsök. A beteg ebben a fázisban is igen fertőző. Az elsődleges fekélyhez hasonlóan ezek a kiütések is elmúlhatnak, ha nem is kap megfelelő kezelést a fertőzött egyén. Hosszú idő múlva kialakulhat a szifilisz harmadik fázisa, amely már nem fertőző. Csomók (gummák) megjelenése kíséri és az idegrendszert is érinti. ${ }^{11}$ Magyarországon a szifilisz az 1980-as években szinte alig fordult elő az akkor hatályban levő szigorú kontaktkutatás és az azt követő (akár hatósági előállítás által) kötelező antibiotikumkezelésnek köszönhetően. Ezt követően viszont az esetek száma emelkedett. Az elmúlt években éves szinten a szifiliszes esetek száma meghaladta a 600at. 2015-ben 617 esetet regisztráltak. A 2. ábra alapján jól látható, hogy ebből 34 esetben a 15-19 
éves fiatalokat érintette, ami tovább hangsúlyozza az oktató-nevelő munka fontosságát a szexuálisan terjedő betegségek tekintetében. ${ }^{8}$ A szifilisz egyelőre jól kezelhető antibiotikummal. Sajnos terjedőben vannak a különböző antibiotikumoknak ellenálló baktériumok, és néhány régióban ezek lettek a domináns törzsek.

2. ábra: A szifilisz előfordulása Magyarországon 2015-ben

A

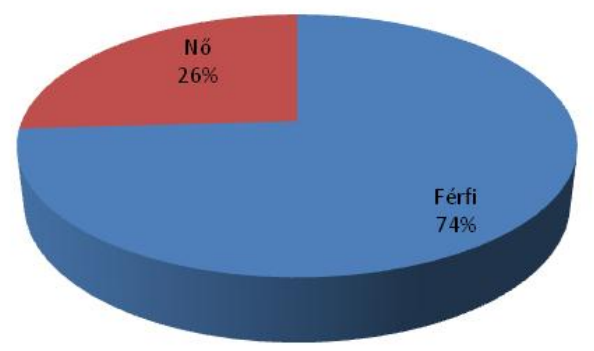

B A szifilisz előfordulása kor szerint, 2015

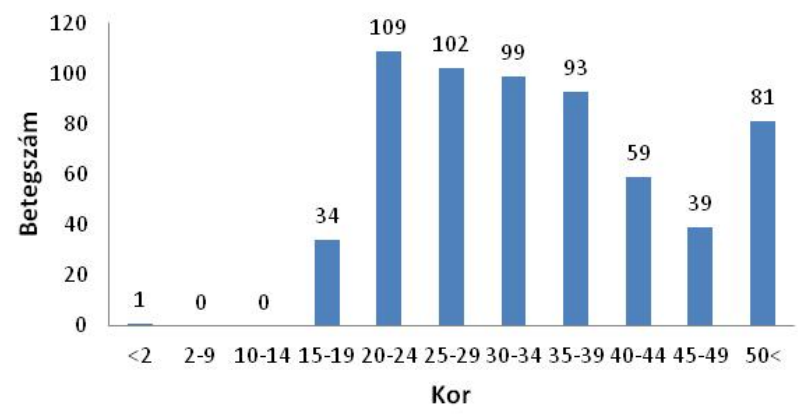

Adatok forrása: Epinfo, 2015 (saját szerkesztésú ábrák)

\section{BAKTERIÁLIS VAGINOSIS}

Bár nem sorolják a szexuálisan átvihető betegségek közé, ismerete fontos lehet a fiatal lányok, nők számára. A vaginosis a hüvely gyulladását jelenti, amit a baktériumok speciális csoportjának túlszaporodása okoz. Ezek a baktériumok oxigénmentes környezetben is tudnak szaporodni (anaerobok). Leggyakrabban akkor alakul ki ez a kép, ha a hüvelyből kipusztulnak a jótékony Lactobacillusok (például széles spektrumú antibiotikum szedését követően), és így a pH megemelkedik. Ennek következtében az anaerob baktériumok elszaporodnak, és sárgás színú bűzös folyást (rothadó halszagra emlékeztet) okoznak. A bakteriális vaginosis könnyen gyógyítható olyan antibiotikumokkal, amelyek anaerob baktériumok ellen is hatásosak. ${ }^{12}$

\section{CANDIDIASIS}

A nemi szervek gyulladását okozó Candida albicans és a Candida genus egyéb tagjai a médiának köszönhetően talán a legismertebbek. A candidák rendszertanilag az élesztőgombák közé sorolhatók. Emberben nagy számban megtalálhatók az emésztőrendszerben. Korábban úgy gondolták, hogy a candidák terjedésében a szexuális együttlétet játszik szerepet. Ma már tudjuk, hogy a fertőzés forrása belső (endogén), általában a végbél mikroflórája. Ezért igen fontos a kislányokat már gyermekkorban megtanítani a vizeletürítést követően a törlés helyes irányára. Ha ez nem megfelelő, sajnos könnyen élesztőgombák törölhetők a hüvelybe. Fiatal lányoknál egyéb tényezők is hajlamosítanak (például tanga alsó) candidiasisra. A hüvelyben normális körülmények között is előfordulhatnak candidák, viszont a számuk erősen korlátozott az alacsony pH-érték miatt, amelyet a lactobacillusok tartanak fenn. Sajnos, ezt a finom egyensúlyt az orvos által egyéb okok miatt, például torokgyulladásra felírt antibiotikum megbonthatja, ha az elrendelt antibiotikum megöli a jótékony lactobacillusokat. Ennek következtében a pH megemelkedik, ami már kedvez a candidák szaporodásának. A candidiasis legfontosabb tünete a fehér színú folyás, ami a szeméremtest fájdalmas gyulladását is okozhatja. A folyás állaga alapján, mivel fehér és a hüvely falán túrószerű felrakódásként jelentkezik, könnyen elkülöníthető más betegségektől. A gombás eredetű folyások általában jól reagálnak helyi (hüvelytabletta, krém) antimikotikus kezelésre. ${ }^{13}$ 


\section{TRICHOMONIASIS}

A betegség okozója a Trichomonas vaginalis, amely rendszertanilag a véglényekhez tartozó, körte alakú, gyorsan mozgó, ostoros, egysejtű parazita. Egyszerű, bináris hasadással szaporodik. Eltérően a legtöbb véglénytől nincs ciszta alakja, csak vegetatív formával rendelkezik. A kórokozó általában szexuális úton terjed, de otthoni körülmények között, közös fürdő során, illetve közös használatú törölközővel átvihető. Korábban leírtak nem megfelelően sterilizált nőgyógyászati eszközök okozta terjedést is, de az egyszer használatos eszközök bevezetésével ez a módja az átvitelnek kiküszöbölhetővé vált. A betegség inkubációs ideje 3-5 nap. A kórokozó nők esetében főleg a hüvelyt, férfiaknál a húgycsövet fertőzi meg. A trichomoniasis legfontosabb tünetei nők esetében a habos, zöld színű, búzös hüvelyi folyás. A váladék a szeméremtest felmaródását okozhatja. A trichomonasfertőzés kedvez más kórokozók felszálló fertőzésének, ugyanis a patogén az ostorával mozogva fellazítja a méhnyakban található nyákdugót. Férfiak esetében a fertőzés sokszor tünetmentes. Amennyiben tüneteket okoz, leginkább csípő, égető érzés jelentkezhet a húgycsőben, főleg a reggeli vizeletürítést követően, ami a húgycsőgyulladás (urethritis) jele. A kórokozó megtelepedhet még a prosztatában, a mellékherében és a húgyhólyagban is. A trichomonas nagyon könnyen terjed a népesség körében - Magyarországon a fertőzöttségi arányt a felnőttek körében 20\%-ra becsülik -, mivel a fertőzés általában nem okoz tüneteket egyik nemben sem. A trichomoniasis egyszerüen kezelhető olyan antimikrobiális szerrel, amely a véglényekre is hat. A kezelés szempontjából a legfontosabb, hogy a partnert mindenképp kezelni kell, a trichomoniasis ugyanis tipikus „pingpongbetegség”, vagyis a partner kezelés hiányában visszafertőzheti kezelt partnerét. ${ }^{14,15}$

\section{ÖSSZEGZÉS}

A nemi betegségeket különböző mikroorganizmusok okozzák, különböző tüneteket produkálva. Fontos, hogy a középiskolás korúak ismerjék szervezetüket és figyeljenek fel a megszokottól eltérő múködésére. A nemi betegségek megelőzésében fontos a megbízható partner és a megfelelő fizikai védelem, így az óvszer használata. Természetesen ez nem nyújt 100\%-os védelmet, de használatával jelentősen csökkenthető a fertőző betegségek átvitelének a kockázata. Ha valami rendelleneset tapasztalnak, nem tanácsos öngyógyításba kezdeni, azzal ugyanis elfedhetnek olyan tüneteket, amelyek az orvos számára fontosak lehetnek a diagnózis megállapításában. Feltétlenül keressék fel a gyermeknőgyógyászati szakambulanciát vagy a nemibeteg-gondozó intézetet, ahol szakszerű ellátást kapnak a fiatalok. A prevenciónak azonban kulcsszerepe van, még a szexuális élet megkezdése előtt. Sok esetben nem valósítható meg, hogy az iskola vállalja fel a szexuális úton átvihető fertőzések ismeretanyagának átadását, de szakemberek bevonásával és a biológia-egészségtan tanárok továbbképzésével a helyzeten javítani lehetne.

\section{Köszönetnyilvánítás}

A szerzök az MTA-SZTE Mikrobiológia és Egészségnevelés Szakmódszertani Kutatócsoport tagjai, akik köszönetet mondanak az MTA Tantárgypedagógiai Kutatási Programnak a közlemény létrejöttének támogatásáért. 


\section{HIVATKOZÁSOK}

\footnotetext{
${ }^{1}$ Groves MJ. Genital Herpes: A Review. Am Fam Physician. 2016;93(11):928-34.

${ }^{2}$ Garland SM, Steben M. Genital herpes. Best Pract Res Clin Obstet Gynaecol. 2014;28(7):1098-110. doi: 10.1016/j.bpobgyn.2014.07.015.

${ }^{3}$ Egawa N, Doorbar J. The low-risk papillomaviruses. Virus Res. 2017;231:119-27. doi: 10.1016/j.virusres.2016.12.017. ${ }^{4}$ Bonanni $\mathrm{P}$, Bechini A, Donato R, et al. Human papilloma virus vaccination: impact and recommendations across the world. Ther Adv Vaccines. 2015;3(1):3-12. doi: 10.1177/2051013614557476.

${ }^{5}$ Chen X, Anstey AV, Bugert JJ. Molluscum contagiosum virus infection Lancet Infect Dis. 2013;13(10):877-88. doi: 10.1016/S1473-3099(13)70109-9.

${ }^{6}$ Nelson HD, Zakher B, Cantor A, et al. Screening for Gonorrhea and Chlamydia: Systematic Review to Update the U.S. Preventive Services Task Force Recommendations [Internet].Rockville (MD): Agency for Healthcare Research and Quality (US); 2014 Sep. PMID: 25356451

${ }^{7}$ Fanfair RN, Workowski KA. Clinical update in sexually transmitted diseases - 2014. Cleve Clin J Med. 2014;81(2):91101. doi: 10.3949/ccjm.81a.13090.

${ }^{8}$ Szexuális úton terjedő fertőzések, Magyarország, 2015. Epinfo. 2016;23(19-20):229-39. http://epa.oszk.hu/00300/00398/00684/pdf/EPA00398 epinfo 2016 19-20.pdf Elérve: 2017. 10. 02.

${ }_{9}^{9} 2014$ Sexually Transmitted Diseases Surveillance Chlamydia. November 17, 2015. Retrieved 10 June 2016. https://www.cdc.gov/std/stats14/chlamydia.htm Elérve: 2017. 09. 27.

${ }^{10}$ GBD 2015 Disease and Injury Incidence and Prevalence, Collaborators. Global, regional, and national incidence, prevalence, and years lived with disability for 310 diseases and injuries, 1990-2015: a systematic analysis for the Global Burden of Disease Study 2015. Lancet. 2016; 388(10053): 1545-602. doi:10.1016/S0140-6736(16)31678-6 ${ }^{11}$ Cohen SE, Klausner JD, Engelman J, et al. Syphilis in the modern era: an update for physicians. Infect Dis Clin North Am. 2013;27(4):705-22. doi: 10.1016/j.idc.2013.08.005.

12 Verstraelen $\mathrm{H}$, Verhelst R. Bacterial vaginosis: an update on diagnosis and treatment. Expert Rev Anti Infect Ther. 2009;7(9):1109-24. doi: 10.1586/eri.09.87.

${ }^{13}$ Creatsas G, Deligeoroglou E. Microbial ecology of the lower genital tract in women with sexually transmitted diseases. J Med Microbiol. 2012;61(Pt 10):1347-51. doi: 10.1099/jmm.0.042507-0.

${ }^{14}$ Huppert JS. Trichomoniasis in teens: an update. Curr Opin Obstet Gynecol. 2009;21(5):371-8. doi: 10.1097/GCO.0b013e32832e0827.

${ }^{15}$ Kissinger P. Trichomonas vaginalis: a review of epidemiologic, clinical and treatment issues. BMC Infect Dis. 2015;15:307. doi: 10.1186/s12879-015-1055-0.
} 